\title{
Institutions AND EConomic Change: A Critical SuRvey of THE NeW INSTITUTIONAL APPROACHES AND EMPIRICAL EVIDENCE
}

\author{
Francesca Gagliardi* \\ The Business School, University of Hertfordshire (UK)
}

Published in The Journal of Socio-Economics, 2008, 37, pp.416-443

\begin{abstract}
The purpose of this paper is to review the main literature that has analyzed the channels through which institutions influence economic change, hence development. The interest for this topic arises from the relatively recent consensus that has emerged among scholars and policy makers in considering institutions a key factor shaping the outcome of the economic game. The aim is pursued by discussing the theoretical approaches proposed within the New Institutional Economics to inquiry on institutional issues. Besides, the empirical evidence resulting from some of the studies that have lately investigated the nexus between institutions and economic performance is presented as well.
\end{abstract}

JEL classification: B52; D02; O10.

Keywords: Institutions; Institutional Analysis; Economic Change.

\footnotetext{
* The Business School, University of Hertfordshire, Department of Accounting, Finance and Economics, De Havilland campus, Hatfield, Hertfordshire, AL10 9AB, UK. Tel.: +44 (0)1707 285570; Fax: +44 (0)1707 285455. Email: f.gagliardi@herts.ac.uk.
} 


\section{INTRODUCTION ${ }^{\circ}$}

In recent years the role of institutions in promoting and sustaining economic change has been an issue of interest for both theoretical and empirical analyses in the social science literature (see for example Stiglitz, 1998 and World Bank, 1993, 1997). It could be argued that this renewed interest arises from the consciousness that in all actions we pursue as economic agents, we are affected by institutions. This concept has been given different meanings in the economics literature (see - only to quote a few contributions - Davis and North, 1971; Klein, 1998; Acocella, 1999; Arrighetti and Seravalli, 1999a; Aoki, 2001); however, by regarding the economic process as a game it is possible to identify three main definitions of institutions. ${ }^{1}$ Firstly, institutions are conceived as the rules of the game (North, 1990; Ostrom, 1990): they are the set of norms identified by individuals to discipline their relationships (a technical formulation of this view has been proposed by Hurwicz, 1993 and 1996). Secondly, institutions are defined as the players of the game (Nelson, 1994); along with the rules in force, this definition considers also the role played by those who have to apply the rules and ensure they are respected by others, as well as the organizations. In this context, examples of institutions are universities, courts, industry associations, government agencies etc. Finally, the third definition considers institutions as the self-enforcing equilibrium outcome of the game (Schotter, 1981). More precisely, institutions are made up of two interrelated elements: the beliefs individuals form on others' behavior and the organizations, which can alter the rules of the game. This last view has been further elaborated by using the evolutionary game approach (see Aoki, 1995; Bowles, 2001; Sugden, 1986 and 1989; Young, 1998, among others) and the repeated game approach (Calvert, 1995; Greif, 1989, 1994a, 1997a and 1998a; Greif et al, 1994; Milgrom et al, 1990).

From a methodological point of view, the investigation of the relationship existing between institutional framework and economic performance has been pioneered by the establishment of a particular

\footnotetext{
' I am grateful to Geoffrey M. Hodgson, William Jackson, Rosanna Nistico', and an anonymous referee for their valuable comments and suggestions on earlier versions of this paper. Of course, all remaining errors are mine.

${ }^{1}$ For an extensive discussion on these three different definitions see Aoki (2001) who clarifies that the meaning to be attributed to the term "institution" largely depends upon the purpose of the analysis.
} 
strand of analysis: the New Institutional Economics. ${ }^{2}$ According to many scholars, the origins of this branch of analysis can be traced back to Coase (1937), ${ }^{3}$ whose most important message is that when it is costly to transact, institutions matter. ${ }^{4}$ Subsequent studies (Williamson 1975, 1979, 1985, 1996) led to the development of the transaction costs approach, which enriches the analysis by incorporating, amongst other things, two behavioral assumptions: individuals’ bounded rationality (Simon, 1947) and self-oriented behavior.

As a result of the numerous studies carried out in the field of the New Institutional Economics, a widespread consensus has emerged among scholars in considering institutions a key factor in explaining different economic performance across diverse economies (see, among others, Nelson and Sampat, 2001; North, 1990; World Bank, 2003). ${ }^{5}$ The basic argument for such a view is that individuals can capture the gains from trade by cooperating. However, since cooperation is costly and harmed by opportunism, it appears necessary to identify some device to overcome these problems. The evolution of institutions can produce a favorable environment for the adoption of cooperative solutions that will foster economic change, hence growth.

The mechanisms through which the emergence and evolution of institutions create a favorable ground for economic development have been variously investigated, both theoretically and empirical-

\footnotetext{
${ }^{2}$ The term "New Institutional Economics” was first used by Williamson (1975) in order to make a distinction between this approach and the "Old Institutional Economics". Among the most influential contributions in the field of the old institutionalism are the works of Commons (1931) and Veblen (1899, 1919). For analyses on the relationship between Old and New Institutional Economics, see - among others - Coase (1998), Hodgson (1998), Klein (1998), Rutherford (1994, 1995, 2001), and Williamson (2000).

${ }^{3}$ Coase (1998) stresses the relevance for the emergence of the New Institutional Economics of contributions of other economists, such as Williamson, Demsetz and Cheung, and of studies carried out in fields other than economics, such as sociology, law, anthropology and political science.

${ }^{4}$ Wallis and North (1986) have demonstrated that transactions among individuals are costly.

${ }^{5}$ It is worth noting that the New Institutional Economics is only one of the possible perspectives from which institutional and development issues can be analyzed. Another stand of literature, for instance, is that of "Varieties of Capitalism” (Hall and Soskice, 2001).
} 
ly. However, to my knowledge, a review that combines theory and empirical evidence is still missing. Therefore, the aim of the present work is to provide a contribution to fill this gap.

From a theoretical point of view, it is possible to identify three broad categories of approaches to the study of institutional issues. The first will be here referred to as "the historical perspective" and its pioneer can be identified in North (1990) with his seminal book Institutions, Institutional Change and Economic Performance. The second interpretative framework is that of "comparative institutional analysis”, whose most systematic elaboration has been provided by Aoki (2001). ${ }^{6}$ The third strand of analysis is the "imperfect information theory", which explains institutions in terms of strategic behavior under asymmetric information among the different parties involved (Bardhan, 2000). A major difference between these three approaches lies in the analytical tools used to carry out the investigation. Indeed, while North and his followers attempt to integrate economic theory and economic history, those affiliated to the comparative institutional approach not only rely on historical information, but make an extensive use of game theory as well. Besides, with regard to the imperfect information framework, this is more mathematically oriented than the other two lines of study (Nabli and Nugent, 1989).

As far as the empirical literature is concerned, the existing evidence seems to provide support to each of the above mentioned theoretical approaches, thus suggesting that they all contribute to explain the channels through which institutions are relevant for economic performance.

The strategy of the present survey will be to briefly discuss in section two the reasons underlying the importance of incorporating institutions in economic analysis. The next step will be to review the main contributions proposed in each of the aforementioned theoretical approaches with the aim to highlight their usefulness in understanding the nexus institutions-economic development, as well as their limitations. This will be the object of the third, fourth and fifth sections. Attention will be de-

\footnotetext{
${ }^{6}$ It is worth noting that the “comparative institutional analysis” approach does not rely solely on Aoki's (2001) elaboration. Indeed, it has benefited from several contributions, such as the one offered by Aoki (1996) himself and Greif (1997b and 1998a). However, it is only with Aoki (2001), in his Toward a Comparative Institutional Analysis, that the work previously done in this line of study finds a systematic treatment.
} 
voted in section six to comment on the results of the main empirical works carried out on these issues. Finally, the seventh section concludes.

\section{WHY DO INSTITUTIONS MATTER?}

Social scientists have their attention focused on human interaction in contexts where the interests of one party - and the efficacy of the actions of that party - are strongly influenced by what other parties do (Nelson and Sampat, 2001). This concern is due to the fact that the strategic complementarities existing between economic agents imply that in many situations collective action initiatives can assure benefits unavailable through individual action. Therefore, successful collective action initiatives can be regarded as welfare improving. It is for this reason that the issue of collective action has been variously investigated in order to gain some insights on the factors that influence its starting, maintenance and success.

A seminal work in this strand of literature is the rational choice model proposed by Olson (1965). ${ }^{7}$ He argues that rational and self-interested individuals choose their action plans to pursue personal interests; therefore, they are inclined to act opportunistically, leaving others to bother for the costs that must be sustained to achieve the desired result. ${ }^{8}$ This behavior produces the socially sub-optimal outcome described in the prisoner's dilemma.

Along with free riding, a second threat to the start-up of collective action comes from the coordination costs that individuals have to bear to order and select the optimum equilibrium, to decide the agents to involve in the project, the technology to be used etc. These costs are generated by the very nature of strategic complementarities, which involves a multiplicity of possible equilibria (Arrighetti and Seravalli, 1999b).

\footnotetext{
${ }^{7}$ Among the main assumptions of the rational choice model are: rational and wealth maximizing agents, perfect information, full comprehension of the game structure, and simultaneity and independence of agents' action choices.

${ }^{8}$ Exceptions to this behavioral pattern, according to Olson (1965), are possible when the number of interacting agents is small and incentives are provided in order to selectively reward or punish.
} 
The idea that, because of free riding and coordination costs, individuals are not willing to cooperate even when this could be mutually beneficial - has been variously addressed in the study of social dilemmas. ${ }^{9}$ Empirical research has shown that everyday life does not provide support to this hypothesis: cooperative behaviors are widespread and in several circumstances individuals spontaneously choose to cooperate with others in order to gain mutual benefits (see Milgrom et al, 1990; Bromley, 1992; Ostrom, 1998 and 2000, among others). It is in this context that the key role of institutions can be identified: institutions matter because they contribute to solve problems of coordination of agents' plans; help to promote cooperative behavior and overcome opportunism; make agents internalize externalities, and reduce uncertainty. They support the formation of social capital and of a historical experience of collective action which, in turn, positively affect the likelihood to credibly commit in cooperative strategies.

Ostrom (1998) argues that trust, reputation and reciprocity are three key attributes of human behavior that influence the willingness to establish cooperation and to sustain it through time. Indeed, when individuals reciprocate each other, there exists for them an incentive to acquire a reputation by keeping to their promises and carrying out actions whose long run benefits will outweigh the short run costs. ${ }^{10}$ This mechanism allows individuals to establish mutually beneficial relationships based on trust. In this model the circular relation between trust, reciprocity and reputation - combined with a long temporal horizon and influenced by contextual variables - increases the level of cooperation amongst individuals, thus creating the ground for successful collective action initiatives. In this context, it could be argued that institutions able to provide the right set of incentives can foster the set up of the above described circular relation, thus allowing and facilitating the diffusion of cooperative behaviors.

\footnotetext{
${ }^{9}$ Ostrom (1998) refers the term "social dilemmas" to the decisions undertaken by economic agents in contexts characterized by a high degree of interdependence and conflict.

${ }^{10}$ An interesting contribution on the issue of reputation has been proposed by Tirole (1996). In this work the joint dynamics of individual and collective reputations are investigated in a model in which current generations are progressively replaced by new ones. The main result is that individual reputations are determined by collective reputations, and vice versa. In particular, a member's incentive to maintain an individual reputation is stronger, the better the group reputation is.
} 
Clearly institutions are not the only factor that explains the adoption of stable forms of cooperation. Spagnolo (1999), for instance, addresses the influence of social relations on agents' ability to cooperate in the workplace. Typically, team relations are subject to the risk of free-riding since each member has an incentive for cheating on the others. The idea is, therefore, that long term social relations between team members are a form of strategic interaction, which tends to become linked to production strategic interactions. The result of linking the two types of relations is that cooperation in production can be enhanced. This happens because when workers share also social relations, the available social capital can be profitably invested to enforce cooperation in production. ${ }^{11}$

Recently, Ahn and Ostrom (2003) have presented an analysis of the factors facilitating cooperation that includes the role played by social capital. In this approach, social capital - defined as a set of prescriptions, values and relationships created in the past that can be used in the present and future to overcome social dilemmas - has the forms of trustworthiness, networks, and institutions. ${ }^{12}$ Besides, there exist complex causalities among the different forms of social capital: trustworthiness and networks affect and are affected by the kind of institutions that have evolved and, at the same time, institutions depend on the existent networks and levels of trustworthiness. Through this dynamic process, the authors argue, it is possible for individuals to achieve mutual trust and establish cooperation, therefore increasing their long run net benefits. Extending this reasoning at an aggregate level, it could be argued that institutions are social technologies shaping economic performance (Nelson and Sampat, 2001).

\footnotetext{
${ }^{11}$ However, Spagnolo (1999) shows that even when no social capital is available before the linkage, a firm may still find profitable to choose employees who share social relations. In this case, the enforcement mechanism works by the threat to interrupt cooperation in both relations if one agent cheats in the production relation. As a result, linking social and production relations may allow cooperation to be sustained in both relations, even when it would otherwise not be sustainable in any of them.

${ }^{12}$ These latter - conceptualized as the rules of the game - are capital in the sense that they serve as independent inputs to economic and political processes and outcomes. More in detail, institutions help individuals to gain more trust in the trustworthiness of others (i.e. they increase the individuals' preference for being trustworthy), as well as using networks as a way of investing in better institutions.
} 


\section{THE HISTORICAL PERSPECTIVE}

\subsection{The general framework}

The approach proposed by North (1990) to the study of institutions represents an attempt to construct an analytical framework that integrates institutional analysis into economics and economic history in order to explain the factors that account for the different patterns of economic performance experienced by diverse societies. Previous research on this issue has been carried out, among others, by Alchian (1950) with his evolutionary hypothesis, and North and Thomas (1973) that have offered an efficient explanation later confuted by North (1981) himself.

Since much of the developmental path of societies is conditioned by their past, institutions are historically specific. For this reason it is necessary to be sensitive to the historical context, especially when dealing with the issue of institutional change (Alston, 1996). North (1990) attempts to accomplish this purpose by combining a theory of human behavior with a theory of transaction costs. For what concerns the behavioral assumptions, two major hypotheses deserve to be discussed. In the first place, North argues that the rational choice theory, as it relates to institutions, is inadequate. Indeed, the neoclassical utility function does not take into account motivations other than the wealth maximizing one, whilst - as the growing experimental economics literature has shown - individual choices are often guided by altruism or by institutions in the form of self-imposed constraints. A second hypothesis assumes that to solve the problems they confront, individuals process the information available by using pre-existing mental models.

Turning to the aspect of transaction costs, these arise from the costliness of information and must be sustained to attribute value to the objects of exchange, to protect rights, and enforce contracts. The set of these costs, North argues, is the very reason for the existence of institutions. More in detail, institutions determine the structure for exchange that - combined with the technology employed - influences transaction and transformation costs and, hence, the feasibility and profitability of engaging in economic activity. It is through this mechanism that institutions are the underlying determinant of long run economic performance.

Stated differently, institutions have the role of structuring human interaction in a stable, although not always efficient, way and this objective is accomplished by reducing the uncertainty that pervades 
all societies. That this is the basic function of institutions clearly descends from North's definition of institutions. Indeed, the author considers institutions as "the rules of the game in a society" (North, 1990 p. 3), meaning that all the formal rules (such as contracts, and political and economic rules) and the informal norms ${ }^{13}$ (e.g. conventions, codes of conduct and norms of behavior) individuals conceive to regulate their relationships define the set of institutions in force in a society at a certain point of time. ${ }^{14}$ By defining and limiting the set of choices available to economic agents, institutions structure the incentives in human exchange. Clearly, under limited information and computational ability, constraints reduce the costs of human interaction as compared to a world of no institutions.

An important distinction in North's theorization is between institutions (the rules of the game) and organizations (the players). The latter are groups of individuals - such as political, economic, social, and educational bodies - bound by some common purpose to achieve objectives. However, institutions and organizations are interdependent entities: the institutional framework determines the opportunities in a society and the emergence and evolution of certain organizations, created with the purpose of making profitable those opportunities. In turn, organizations influence how institutions evolve, thus being agents of institutional change. In particular, the evolution of organizations alters institutions in an incremental manner, which critically depends on how individuals perceive and process the information about wealth improving opportunities.

It is worth at this stage to point out that Hodgson (2006) has recently clarified that in conceptualizing organizations as players of the game, North (1990) is making an analytical abstraction, rather than defining organizations in this way. In a correspondence with Hodgson, in fact, North himself has specified that he treats organizations as players simply for the purpose of analysis of socio-economic systems as a whole. In other words, North is not saying that organizations are not institutions; he is just

\footnotetext{
${ }^{13}$ Being a cultural by-product, informal constraints are embedded (Granovetter, 1985) in the society and, thus, are more impervious to deliberate policies than formal rules in the sense that they will not change immediately in response to changes in the formal constraints.

${ }^{14}$ Hargreaves Heap (1994) offers a definition of institutions close to the one proposed by North and clarifies that institutions guide human behavior "by supplementing the conventional utility maximizing calculation” (p. 36).
} 
not interested in the social rules internal to organizations because he wants to treat them as unitary players and focus on interactions at national or other higher levels (Hodgson, 2006).

\subsection{Path dependence}

A crucial conclusion in this analytical framework is that the process of institutional change is incremental and largely path dependent. ${ }^{15}$ In particular, an institutional change starts to occur when, following a variation in relative prices and/or in preferences, the parties to an exchange become aware that to be better off they need to renegotiate the terms of their agreements by restructuring the existing set of rules. However, when a path is set on a particular course, the network externalities, the learning process of organizations and the historically derived subjective models reinforce the course in a path dependent way (North, 1990).

Puffert (1999) has argued that theories of path dependence imply a role for history, and in particular for economic history, in explaining both the past and present. ${ }^{16}$ Clearly, this supports the claim that the timing of events matters (Pierson, 2004). The approach of path dependence, besides the neoclassical postulates of scarcity and competition, adds the hypotheses of incomplete information, subjective models of reality and increasing returns of institutions. This interpretative framework allows connecting microeconomic activity with the macroeconomic incentives offered by the institutional framework, thus providing analytical insights of long run economic change (North, 1990). Besides, path dependence implies that if the process that leads to the emergence of a particular set of institutions is relevant and constraints future choice, then not only history matters ${ }^{17}$ but, more important,

\footnotetext{
${ }^{15}$ The concept of path dependence was pioneered by David (1985) and Arthur (1989). Broadly speaking, a process is said to be path dependent when actual and future outcomes are influenced by previous patterns.

${ }^{16}$ Other contributions on path dependence and institutional change have been offered, among others, by Kiwit (1996), Mahoney (2000, 2001a and 2001b), Pierson (2000) and Thelen (1999).

${ }^{17}$ The claim "history matters” refers to what Page (2005) calls "equilibrium path dependence”: what happens in the long run depends upon the past. This is different from "outcome path dependence", which means that what happens in this period depends upon the past.
} 
poor performance and long run divergent patterns of development are determined by the same source. Path dependence may, therefore, explain why some countries succeed and others do not (Easterly, 2001). Indeed, economic growth models predict that less developed countries should catch up with their richer counterparts, whilst the evidence shows that this has not happened, thus giving support to the path dependence conjecture. ${ }^{18}$

Alterations in a given path are however possible and, basically, are due to unanticipated effects of choices and to external effects; moreover, the reversal of a given path is typically determined through changes in the polity (North, 1990). Notwithstanding this recognition that change is possible, it could be argued that a weak point of this conceptualization is the difficulty of identifying what kind of actions individuals can concretely undertake to become agents of change and, through this way, of economic development. Crouch and Farrell (2004), for instance, claim that the path dependence approach cannot be used to investigate how actors copy with contextual change since this possibility is not explicitly modeled. To gain some insights on the issue of institutional stickiness, ${ }^{19}$ they propose a model in which a Bayesian parametric decision maker interacts with a specific environment. Their purpose is to investigate how individuals may respond to environmental changes by modifying their institutional responses. Two main conclusions come out from this analysis: firstly, the path of institutional development is not unique, although only one among several is selected; secondly, even though for given sets of parameter values the actual path will be difficult (or costly) to change, the model sets out a set of conditions under which change can occur.

\footnotetext{
${ }^{18}$ To illustrate this argument, North (1990) argues that the divergences in the economic histories of South and North America may in large part be due to the differing initial institutional matrices they derived from Spain and Britain, respectively. Therefore, persistent inefficient equilibria may result from initial choices.

${ }^{19}$ The term institutional stickiness, as Crouch and Farrell (2004) point put, refers to those situations in which actors may fail to respond to changes in the environment even when such responses would lead to a better overall outcome.
} 
In an attempt to formalize the approach of path dependence, Schwartz (2003) argues that three logically connected arguments must be taken into account. ${ }^{20}$ Firstly, small contingent causes at the beginning of a path can have long lasting effects (Mahoney, 2000; Pierson, 2000); secondly, increasing returns to institutions are a mechanism for institutional reproduction and allow to explain why agents often refrain from modifying the existing institutions; finally, there exists an analogy between path dependence’s “critical junctures” (Collier and Collier, 1991) and the evolutionary concept of punctuated equilibrium. On this latter point Schwartz elaborates further claiming that institutional evolution is a consequence of the exogenously induced process of institutional change. Therefore, the role of "critical junctures" - which can be defined as moments that increase or decrease actors' range of choice among competitive alternatives - is to separate the exogenous mechanisms for production from the endogenous increasing returns for reproduction. Schwartz (2003) points out that also North (1990), who underlies much of Pierson (2003), rests on the above arguments since both works are based on Arthur's (1989) technological path dependence. However, according to Schwartz, a flaw in the historical institutionalist literature is the lack of explicit formalization. Indeed, in his view, the absence of a formal treatment of path dependence implies that it simply represents the claim that history matters.

Bednar and Page (2005) have recently claimed that several historical analyses of institutions have shown that culture does play a role in the actual institutional performance of economies. Instead, what is missing is an investigation on the causal linkage between culture and institutional performance. Therefore, they propose a formal model aimed at characterizing the bidirectional feedbacks that do exist between culture and institutions. Their model gives support to the initial hypotheses: the institutional framework influences culture; the order in which institutions are implemented is relevant; the choice of a particular institution is path dependent in the sense that since culture influences the institu-

\footnotetext{
${ }^{20}$ Generally, path dependence formalizers present the works of Gerschenkron (1962), Ertman (1997) and Moore (1996) as examples of path dependence/historical institutionalism because of the temporal and institutional features they share.
} 
tional performance and vice versa, the existing set of institutions affect the performance of a new institution.

This contribution is similar to the one offered by North (1990) with respect to the path dependence argument: to understand how new institutions perform, Bednar and Page argue, the past must be taken into account. However, contrary to North (1990), the authors do not attempt to provide an explanation for different patterns of economic growth or political stability. Furthermore, in this model path dependence is caused by institutional externalities rather than by increasing returns. On this latter point, Page (2005) shows that increasing returns are neither necessary nor sufficient for historical path dependence (North, 1991; David, 1985; Arthur, 1994; Pierson 2000). More in detail, Page demonstrates that for the emergence of path dependence the existence of negative externalities (caused by the prevailing constraints) is a necessary, although not sufficient, condition. Indeed, externalities need to be unanticipated as well, since path dependence hinges on a lack of perfect foresight.

\section{THE COMPARATIVE INSTITUTIONAL APPROACH}

The comparative institutional approach has recently been developed to investigate issues regarding institutions and institutional change. Of particular relevance are questions related to the emergence of particular types of institutions and their impact on the diverse spheres that contribute to build up a society (Greif, 1998b). In this analytical framework, institutions are conceptualized as the endogenously emerging equilibrium outcome of a game; thus, the prominent interest is in investigating how the rules of the game are generated and become self-enforcing through the strategic interaction of the agents, whose behavior is in turn influenced by the self-enforcing constraints determined within the existing set of rules. Therefore, institutions are regarded as non-technological constraints that guide social interaction and provide incentives to maintain certain regularities of behavior (Greif, 1998b).

It could be argued that the novelty of this framework lies in the attempt of analyzing institutions by considering not only the interdependencies existing across economic, political, social and organizational domains, but also those arising across institutions linking different domains (Aoki, 2001). An obvious analytical tool to pursue these goals is the game-theoretic one; however, since game theoretic 
models admit multiple equilibria and very often the solutions depend on the specification of the model, Aoki (2001) argues that a well grounded approach to the study of institutions should make use of historical and comparative information as well. This is exactly what scholars in the comparative institutional framework attempt to do. Moreover, studies in this field make an extensive use of empirical analyses whose main purpose is to investigate the relevance of specific institutions. This aim is pursued by combining historical and comparative evidence with context specific models (Greif, 1998b).

It is possible to identify two sub-strands within the framework of comparative institutional analysis (Greif, 1998b). The first one, in order to investigate the impact of the internalization of traits, focuses on the learning and evolutionary processes of the relevant rules. It mainly relies on evolutionary game theory ${ }^{21}$ and learning models. The second line of research, instead, uses the theory of repeated games to analyze the effects produced by phenomena such as strategic interactions, beliefs, and social structures on the set of rules. According to Aoki (2001) these two approaches are not mutually exclusive, since they can be complementary with respect to the domains they can be applied to. More precisely, given a particular domain, they may imply the emergence of the same equilibrium solution (institution).

The survey of the major contributions proposed within the evolutionary game approach and the repeated game approach will be the object of the next two sub-sections.

\subsection{The evolutionary game approach to institutions}

The evolutionary approach appears to be particularly useful for analyzing the self-enforceability of institutions in the form of norms and conventions. When dealing with these institutions individuals

\footnotetext{
${ }^{21}$ Evolutionary game theory originated as an application of the mathematical theory of games to biological contexts, arising from the realization that frequency dependent fitness introduces a strategic aspect to evolution. Recently, it has become of increased interest to economists, sociologists, anthropologists and social scientists for three main reasons. Firstly, "evolution" may also be referred to the cultural evolution of beliefs and norms. Secondly, the bounded rationality assumption underlying evolutionary game theory is probably more appropriate for the modeling of social systems. Finally, evolutionary game theory is a dynamic theory, thus adding an important element missing from the traditional theory.
} 
evolve personal traits; moreover, the basis for compliance with the implied rules is provided by their being taken for granted, making third party enforcement unnecessary (Aoki, 2001). It could, therefore, be argued that this interpretation differs from the one proposed by North (1990) since this latter approach regards institutions as "humanly devised constraints".

In order to explain how conventions can evolve without conscious design and how they can be selfperpetuating, Sugden (1989) argues that the classical game theory's assumptions of perfect rationality and unrepeated interaction are inadequate. According to the author, a convention is an evolutionary stable self-enforcing pattern of behavior in a game that has two or more evolutionary stable strategies. This equilibrium is such that if followed by the majority of the population, agents that choose to deviate from it will be left worse off than the others. Therefore, a sufficient condition for evolutionary stability is that a given strategy profile represents the unique best reply to itself. Besides, the more people follow a convention, the more - other things being equal - it pays to conform to this behavior, thus implying that conventions can be stable, although not necessarily Pareto efficient. Nonetheless, conventions become norms when people start to believe they must behave in ways that maintain a particular pattern of behavior.

A more formal approach to study how a convention does emerge has been proposed by Young (1993). More in detail, having defined a convention as an equilibrium that everyone expects, the issue under analysis is the process that leads to the emergence of one particular expectation when multiple equilibria exist. Assuming that the game is played repeatedly by different agents having adaptive expectations, incomplete information and can make mistakes, Young shows that since past play has a feedback effect on the expectations and behaviors of the agents, expectations tend to converge to a stable equilibrium in the long run.

Moving to the empirical works carried out using the evolutionary approach, their focus has been mainly on issues related to the emergence of firms and their institutional complementarities with financial systems, labor market and government regulations (Greif, 1998b). In this field, an interesting contribution among others (e.g. Aoki, 1995 and Okazaki and Okuno-Fujiwara, 1996) has been proposed by Aoki (1994). He argues that contemporary production methods involve a team characteristic in which workers interact in a so intense way that the individual contribution is hardly distinguishable. 
Therefore, individuals are often induced to behave opportunistically leaving others to bear the costs of the effort. To deal with this problem, Aoki (1994) proposes a model of governance structure that may effectively control free-riding in team production, although in a second-best manner. The solution to the moral hazard problem is achieved by designing a nexus of contracts among workers, managers, investors, and an intermediary monitoring agent. Furthermore, using a comparative static analysis, the author claims that the proposed model presents an analogy with the Japanese corporate governance structure and the underlying institutional framework. Indeed, the comparative analysis carried out highlights that the co-emergence of the main bank system ${ }^{22}$ - with the role of being the monitoring agent - and the imperfect labor market in the high growth period of the Japanese economy was not casual. Indeed, these arrangements realized a system of complementary institutions that effectively enhanced the productivity of team oriented production.

\subsection{The repeated game approach to institutions}

The theory of repeated games proves particularly effective to analyze the self-enforceability of institutions such as norms, contracts, and various governance structures. Compliance with the rules implied by these institutions is based on the rational beliefs of self-interested agents. Nonetheless, explicit mechanisms of enforcement are devised as well (Aoki, 2001).

In this approach the main focus is basically on two related issues. On the one hand, attention is given to investigate the origins and implications of endogenously determined organizations, which are social entities that individuals consciously design to alter the rules of the game. On the other hand, the constraints induced by behavioral beliefs are the second issue of inquiry (Greif, 1998b).

The focus on the identification of the relevant organizations and on beliefs is, clearly, also the object of the empirical methodology employed. The starting point of the analyses carried out within this

\footnotetext{
${ }^{22}$ The main banks were created in Japan between the 1950s and the 1970s. In that period of accelerate economic growth, several corporations financed their funds through bank borrowing. In particular, they developed diversified debt relationships with several banks and, at the same time, they maintained a unique long term relationship with one single bank (the main bank), which had also the monitoring responsibility.
} 
framework is the formulation, guided by the micro-level exam of the available evidence, of a hypothesis about the relevance of an institution specific to the episode under investigation. Thereafter, this assumption - expressed using a game-theoretic formulation - has to be validated by the empirical evidence. To this end, by taking into account cultural, historical, social and political aspects, the factors leading to the emergence of this particular institution are examined, as well as its implications (Greif, 1998b).

The empirical studies carried out in this strand of analysis have focused on several topics, therefore only a few of them will be reviewed here (the interested reader can find further insights in Greif, 1993; Clay, 1997; Aoki and Dinc, 1997; Fafchamps, 1996, and Greif, 1994b, 1994c, among others). An interesting contribution on the process by which cultural beliefs influence institutional innovation and adoption, as well as cultural and social evolution, is offered by Greif et al. (1994). In this work, the authors analyze medieval trade relationships by applying the theory of repeated games to the interactions occurring between the ruler of a trading center and the merchants. At that time, since merchants ran their business traveling from one trading center to the other, they perceived the need for trading centers to be organized in ways that secured themselves and their property. In particular, merchants feared the opportunistic behavior of the ruler because he could have offered protection with the aim of attracting the merchants to his trading center, and then he could have reneged on this promise. To overcome the ruler's commitment problem and ensure an efficient level of trade, Greif et al. (1994) show that a specific institution - the merchant guild - proved effective in enforcing agreements and promoting coordination, thus allowing successful collective action. The formal model presented by the authors shows that when a coordinating organization is present, there exists an equilibrium at which traders come to the city as long as a boycott has never be announced, whilst none of them comes to trade if a boycott has occurred. On the other hand, the ruler protects merchants' rights as long as a boycott has never been announced and always reneges the promised protection once a boycott has occurred. Greif et al. (1994) show also that, given the strategy adopted by the merchant guild, the ruler's optimal strategy is "do not boycott”. Therefore, the guild - which is an example of organization - and the beliefs on others' behavior represent a case of institutionalized commitment that has exerted a positive influence on economic efficiency. 
The formal and informal institutional foundations of the market, along with the informal systems for the enforceability of contracts are other issues that have been empirically addressed. Among other studies, Greif (1989) examines the economic institution that enabled eleventh century merchants to deal with the contractual problems arising as a consequence of the fact that both merchants and judges possessed incomplete information compared to the so-called overseas agents. ${ }^{23}$ The evidence stemming from the exam of documents containing information on the agency relations existing among a group of traders, the Maghribi, allows Greif (1989) to conclude that these traders used to regulate their relationships through a coalition (a peer organization). In particular, agency relations were established only between agents and merchants participating to the coalition and were regulated by an implicit contract according to which each merchant member would have employed only coalition agents paying them the optimal premium. ${ }^{24}$ Nevertheless, coalition merchants agreed not to employ agents who had cheated. Greif (1989) argues that since both parties had common knowledge that the benefits deriving from being a coalition member depended upon past conduct, and that the long run gains from being a honest member outweighed the short run benefits from cheating, the coalition represents an example of economic institution that has provided the right incentives for the establishment of a reputational mechanism among self-interested individuals. The resulting mutual trust ensured credible commitment and the enforcement of contractual arrangements, thus increasing aggregate wealth.

\subsection{Towards a unified framework for comparative institutional analysis}

The most systematic theoretical treatment in the field of the comparative institutional approach can be attributed to Aoki (2001). In particular, the relevance of this contribution lies in the fact that Aoki's analysis attempts to be inclusive of both the evolutionary and the repeated game frameworks. His de-

\footnotetext{
${ }^{23}$ These agents used to provide services related to the trading activity to merchants who were far away from each other. Therefore, since the merchants could not directly observe all the circumstances that determined the agents' revenues, the latter had an incentive to increase their gains by misreporting. In such a situation, it was necessary to establish some mechanism that could have solved this agency problem.

${ }^{24}$ This is the lowest cost premium for which the long run gain is at least equal to the short run gain.
} 
finition of institution reflects the influence of these two approaches; indeed, the author considers institutions as "self-sustaining systems of shared beliefs" (Aoki, 2001, pag. 10) about how the game is played. As such, institutions convey the relevant information about the game and - being perceived by the agents as significant for the actual implementation of their strategies - they regulate the strategic interaction among individuals through a self-enforcing mechanism.

A further element that signals Aoki's unifying effort can be traced in his discussion on the process of institutionalization, which is the emergence of a convergent belief that generates (and is reinforced by) an equilibrium. According to Aoki (2001), institutionalization may be either autonomous or induced. In the first case, an institution self-organizes within the exogenously determined rules of the game and evolves as a spontaneous order. It is worth noting that there exists a clear analogy between this conceptualization and the previously discussed one proposed by Sugden (1986). Therefore, norms, self-enforcing contracts, common laws and moral codes are examples of autonomous institutionalization. On the contrary, an induced institutionalization is the result of an explicit designed change in the game form, such as a modification introduced in the legislative law. However - given that agents' strategic choices matter - an induced institutionalization does not suffice by its own to achieve an intended outcome, since an institution has to be sustained as an equilibrium outcome of the game as well. Once the endogenous rules of the game are created and sustained, through an autonomous or an induced process, they may become the basis for further institutionalization.

Interesting applications of the equilibrium based approach to institutions concern two classes of linkage of games (Aoki, 2001). The first one is referred to situations of "institutionalized linkage”, whereas the second one relates to the presence of an "institutional complementarity". They will be discussed in what follows.

\subsubsection{Institutionalized linkages}

An institutionalized linkage occurs when agents can strategically coordinate their choices across domains (of the same or different type), thus enriching the set of available choices and enabling the emergence of an institution that is not feasible when individuals make separate decisions in isolated domains. In other words, this linkage may change the information and incentive structures of games, 
therefore making credible some strategic choices that would not have been such otherwise. A particular class of linkage of games is that of social embeddedness; ${ }^{25}$ this refers to those situations in which the social domain embeds another type of domain and enables a strategy profile (that would otherwise not be viable) to be sustained in the latter. Indeed, if a cooperative behavior is not self-enforceable in isolation because it is difficult to exclude free-riders, a cooperative standard may become selfenforcing when the same individuals are simultaneously engaged in a social exchange game that can produce a sufficient amount of social capital. Therefore, the analysis proposed by Spagnolo (1999) and discussed in section 2 of this work, can be considered an application of this specific class of linkage of games. A further interesting contribution - as reported by Aoki (2001) - is offered by Platteau and Seki (2000) in a study on Japanese fisheries communities. They find that cooperative norms and practices - such as the sharing of information on the best fishing location and the synchronization of fishing hours - were widespread among the most productive community group. Indeed, in this group people committed to spend effort in respecting the cooperative arrangements, since this behaviour allowed them to gain a better status and reputation within the community. Nonetheless, group members used to share net incomes among fishing units as well. Since the incurred opportunity costs of cooperation were more than compensated by the social capital created, members belonging to this group were able to increase aggregate profits as compared to non cooperative groups. Therefore, it can be argued that this episode shows that institutionalized linkages can positively influence the economic success of a group of agents and, through this way, of a society.

\subsubsection{Institutional complementarities}

The view that considers economic systems as a set of complementary and mutually reinforcing institutions (Aoki, 2001; Hall and Soskice, 2001; Boyer, 2005, only to quote a few) is fairly recent. Intuitively the term "institutional complementarity" refers to situations in which an interdependence

\footnotetext{
${ }^{25}$ The problem of embeddedness has been initially addressed by Granovetter (1985). The starting point in his analysis is the consideration that the issue of how behavior and institutions are affected by social relations is one of the classic questions in social theory. The main message stemming from Granovetter's work is that economic behavior is closely embedded in networks of interpersonal relations.
} 
among institutions occurs. The relevance of this relationship is due to the fact that since each institution defines a set of constraints, incentives and possibilities that determine agents' strategies, the influence of one institution is reinforced when a complementary institution is present (Amable, 2000). Of course, the complementarity between two institutions has a variable impact depending on the general context in which such a complementarity is embedded (Boyer, 2005).

An important implication of the complementarity hypothesis is that even though the object of an implemented policy is to induce a change in an institution operating in a certain domain, if there is no accumulation of competence supporting the policy objective in the relevant domains and/or if complementary institutions do not exist nor co-emerge, the intention of the government cannot be fulfilled. For instance, the significance of changes introduced in financial structures depends on how they fit the changing features of productive units. The same reasoning applies also to changes introduced in the labor market and in the training system in order to improve firms’ performance.

Several formal elaborations of the institutional complementarities hypothesis and its implications have been proposed in the literature. Amongst these contributions, Boyer (2005) argues that two institutions $\mathrm{E}$ and $\mathrm{E}$ ' are complementary if the performance $\mathrm{R}$ of the conjunction of $\mathrm{E}$ and $\mathrm{E}$ ' is superior to the performance of each institution considered separately:

$R\left(E, E^{\prime}\right)>R(E)$ and $R\left(E, E^{\prime}\right)>R\left(E^{\prime}\right)$.

Therefore, in this analysis complementarity requires that the conjunction of two institutions is Paretoimproving with respect to the existence of only one of the two entities.

As opposed to this conclusion, Aoki (2001) shows that in the presence of synchronic institutional complementarities across domains, the prevailing institutional arrangements are not necessarily Pareto improving, as they may be Pareto suboptimal, as well as Pareto non-rankable. ${ }^{26}$ This model - based on

\footnotetext{
${ }^{26}$ Besides synchronic complementarities Aoki (2001) analyzes also the process of dynamic interaction among complementary domains (diachronic institutional complementarities) to test the effect produced by a parametric change - such as a policy reform, a new statutory law or a technological innovation - on the game forms of complementary domains.
} 
the theory of supermodular games developed by Topkis $(1978,1998)$ and Milgrom and Roberts (1980) - considers two domains, $\alpha$ and $\beta$, that do not directly interact, two sets of agents, $\mu$ and $\sigma$, and two payoff functions, $u$ and $v \cdot{ }^{27}$ It is assumed that an institution operating in one domain will exogenously affect the outcome of the other game by changing its institutional environment. Also, agents in domain $\alpha$ have to choose an endogenous rule from either $\vartheta^{\#}$ or $\vartheta^{\# \#}$, whereas agents in domain $\beta$ have to choose a rule from either $\lambda^{*}$ or $\lambda^{* *}$. Moreover, a rule becomes institutionalized in a domain when it is implemented as an equilibrium choice of the agents in the relevant domain. It is also assumed that for all $i$ and $j$ the following conditions hold:

$u\left(\vartheta^{\#} ; \lambda^{*}\right)-u\left(\vartheta^{\# \#} ; \lambda^{*}\right) \geq u\left(\vartheta^{\#} ; \lambda^{* *}\right)-u\left(\vartheta^{\# \#} ; \lambda^{* *}\right),{ }^{28}$

$v\left(\lambda^{* *} ; \vartheta^{\# \#}\right)-v\left(\lambda^{*} ; \vartheta^{\# \#}\right) \geq v\left(\lambda^{* *} ; \vartheta^{\#}\right)-v\left(\lambda^{*} ; \vartheta^{\#}\right) .^{29}$

Given this set-up, Aoki (2001) argues that if for the agents participating in one or both domains the payoff associated with one rule is not strictly higher than the payoff deriving from the other rule (regardless of which rule is chosen in the other domain), then in each domain agents need to take into account what rule is institutionalized in the other. ${ }^{30}$ Therefore, there can be two Nash equilibria in

\footnotetext{
${ }^{27}$ All agents in each domain have an identical payoff function defined on their own binary choice sets.
}

${ }^{28}$ Inequality (2) implies that the incremental benefit from choosing $\vartheta^{\#}$ rather than $\vartheta^{\# \#}$, increases on domain $\alpha$ for all the players when the institutional environment $\lambda^{*}$ rather than $\lambda^{* *}$ prevails in domain $\beta$. Then, $\vartheta^{\#}$ and $\lambda^{*}$ complement each other.

${ }^{29}$ Inequality (3) implies that the incremental benefit from choosing $\lambda^{* *}$ rather than $\lambda^{*}$, increases on domain $\beta$ for all the players when $\vartheta^{\# \#}$ rather than $\vartheta^{\#}$ prevails in domain $\alpha$. Then, $\lambda^{* *}$ and $\vartheta^{\# \#}$ complement each other. ${ }^{30}$ It is worth noting that conditions (2) and (3) do not exclude the possibility that for the agents participating in one or both domains, the payoff associated with one rule strictly dominates that of the other, regardless of the rule that is chosen in the other domain. If a similar situation does occur, then the preferred rule will be implemented autonomously in each domain. In this case, the equilibrium of the system - and thus the prevailing institutional arrangement - is determined by preference (technology). 
pure strategies, $\left(\vartheta^{\#} ; \lambda^{*}\right)$ and $\left(\vartheta^{\# \#} ; \lambda^{* *}\right)$, which imply that $\vartheta^{\#}$ and $\lambda^{*}$, as well as $\vartheta^{\# \#}$ and $\lambda^{* *}$, complement each other.

In a recent study, Basili et al. (2004) have proposed a principal-agent model to investigate the conditions which make the use of trust beneficial for the parties involved in a transaction. The authors show that since trust generates costs, the willingness to reciprocate does not suffice by itself to resort to trust. By contrast, by inducing cooperation between individuals, the presence of complementary institutions represents a crucial variable to foster the choice of trust (rather than contracts) as a mechanism for governing transactions.

The conclusions reached by the analyses so far presented allow, basically, to agree with Amable (2000) in arguing that taking into account the issue of institutional complementarity has consequences for theoretical research, empirical works and policy recommendations. Basically, the argument here is that it is prominent to study the effects of interacting institutions rather than simply recognize that 'institutions matter'. With respect to empirical research, Amable (2000) claims that it should be expected to find that the sectors of activity specialization of a country reflect the dominant type of institutional configuration. Finally, any policy recommendation aimed at introducing a structural reform should consider the coherence and logic of the whole institutional structure.

\section{THE IMPERFECT INFORMATION THEORY}

Beside the historical and comparative approaches, another influential recent strand of new institutional economics is the one associated with the theory of imperfect information. In this line of study the underlying rational of institutional arrangements and contracts (formal or informal) are explained in terms of strategic behavior under asymmetric information among the different parties involved (Bardhan, 2000). More in detail, this conceptual framework stresses that due to information and enforcement costs some markets will not exist and other markets will be largely uncompetitive, so that, in this context, institutions have at least two major roles: firstly, they are a response to missing markets; secondly, they may help to overcome the information problems that preclude complete markets (Arnott and Stiglitz, 1991; Hoff et al, 1993). 
The imperfect information theory of institutions is closely related to that of transaction costs, since information problems represent a particular source of transaction costs (Stiglitz, 1985; Bardhan, 1989; Nabli and Nugent, 1989). The two approaches, however, have developed quite separately, with the asymmetric information framework being more mathematically oriented (Nabli and Nugent, 1989). More in detail, according to Bardhan $(1984,1989)$ and Stiglitz (1986), the information paradigm provides a well-defined structure, clearly spelling out assumptions and equilibrium solution concepts, fully drawing out the implications of strategic behavior under asymmetric information, and sharply differentiating the impact of different types of information problems. In their view, the imperfect information theory provides, therefore, a rigorous framework for analyzing institutions as substitutes for missing markets in an environment of pervasive risks, incomplete markets, and information asymmetry.

The general approach of information costs economics has proved particularly useful for the analysis of contractual choice (Nabli and Nugent, 1989). The departing point in the economics of imperfect information, as well as in that of transaction costs, is the recognition of the existence of an agency problem in contractual arrangements. The agency concept - firstly applied by Jensen and Meckling (1976) and Williamson $(1975,1985)$ to managerial behavior and the ownership structure of firms can be adopted to analyze any situation in which contracts are incomplete and/or information is asymmetric, and the actions of one individual (the agent) affect another individual (the principal). Indeed, the problems of adverse selection and moral hazard, first identified in the context of insurance markets, have been found to be relevant for a large class of cases where asymmetries of information are present between the parties to a contract. These information problems, leaving scope to individuals’ opportunistic behavior, may lead to market failure unless appropriate incentive mechanisms capable of overcoming them are developed (Hoff et al, 1993), which is exactly what scholars belonging to the imperfect information school attempt to do. ${ }^{31}$ On this respect, Bardhan (1984 and 1989) and Stiglitz (1986) have argued that the imperfect information theory yields more concrete and specific predictions about the design of contracts than the usual presentation of transaction cost theory, with more

\footnotetext{
${ }^{31}$ For some applications of relevance to agriculture and least developed countries, see for instance Akerlof (1970), and Greenwald and Glasspiegel (1983).
} 
attention paid to the details of terms and conditions of varying contractual arrangements under diverse circumstances. In particular, imperfect information theorists give more emphasis to ex ante mechanism design in contracts and less to maladaptation costs incurred when transactions drift out of alignment ex post (Bardhan, 1989).

Stiglitz (1985, 1986), Bardhan (1984, 1988, 1989) and many other authors (see Alston and Higgs, 1982; Braverman and Stiglitz, 1982a and 1982b; Braverman and Guasch, 1986, amongst others) have shown how the approach of asymmetric information can be useful in understanding institutions in both developed and developing countries. With respect to these latter, the imperfect information theory has been applied in modeling many agrarian and other institutions, which are seen to emerge as substitutes for missing credit, insurance and futures markets (Bardhan, 1984, 1989; Stiglitz, 1986). It started with the literature on sharecropping, then on interlocking of transactions in labor, credit, marketing and land lease, on labor tying, on credit rationing, on joint liability in group lending schemes, and so on (Bardhan, 1989). Although remarkable are the merits of the contributions proposed within this line of study, Nabli et al. (1989) argue that a flaw in this literature is that much of the work has been strictly theoretical in nature. The fewer empirical studies have involved cross-sectional comparisons among different individuals or groups at a single point in time, rather than over time, so that, according to these authors, they have generally been unable to separate the influence of information or transaction costs from those of cultural and other differences.

As previously introduced, an important application of the imperfect information paradigm is the theory of rural organization based on rational peasants in environments where information is imperfect and costly. ${ }^{32}$ In this field of research, the works by Cheung (1969), Stiglitz (1974, 1986, 1989), Braverman and Stiglitz (1982a, 1986a, 1986b), and Newbery and Stiglitz (1979), among others, attempt to explain the persistence of sharecropping.

According to Cheung (1969), sharecropping arose because it provided the advantage of risk dispersion while entailing lower transaction costs, than either insurance contracts or fixed rental agreements.

\footnotetext{
${ }^{32}$ According to Hoff et al. (1993), the origins of this line of study can be traced to the works of Cheung (1969), Akerlof (1970), and Stiglitz (1974).
} 
In his view, there are no inefficiencies associated with sharecropping since these contracts specify the amount of labor effort to be expended and, by being sufficiently flexible, allow full compensation for any workers' extra effort.

Stiglitz (1974, 1986, 1989) argues, in line with Cheung (1969), that risk-sharing between landlords and tenants is certainly part of the explanation for the persistence of sharecropping. In fact, in the absence of insurance markets (or other markets for risk), this response to risk aversion on the part of workers is clearly an important economic function (Stiglitz, 1989). However, in his works Stiglitz claims that more important than the risk-sharing function - which could be performed also by a combination of rental and wage contracts (Stiglitz, 1974) - sharecropping represents a compromise between risk and incentive effects, these latter related to the limited ability to monitor the actions of the tenant, or the high costs of doing so (Stiglitz, 1974, 1986, 1989). In other words, sharecropping provides an effective incentive system in the presence of costly supervision, thus representing a compromise between the rental system - in which incentives for effort decisions are "correct” but all the risk is born by the worker - and the wage system - in which the landlord who is in a better position to bear risk, bears all the risk, but in which effort can be only sustained through expenditures on supervision. Therefore, Stiglitz's view emphasizes that it is precisely because of its incentive properties, relative to the relevant alternative (the wage system), that the sharecropping system is employed. ${ }^{33}$

Nonetheless, Stiglitz (1986) also argues that the theory of sharecropping offers an explanation of cost-sharing, which has been proposed as a remedy in all those situations in which there are other important inputs besides labor and land, so that if the worker pays all of the costs, but receives only a fraction of the benefits, he will have an insufficient incentive to supply these other inputs. In such cases, cost-sharing provides the correct incentives since both benefits and costs are shared between worker and landlord. Furthermore, since workers typically have more information about current circumstances than the landlord, a contract which simply specifies the level of inputs cannot adapt to the

\footnotetext{
${ }^{33}$ It is worth mentioning that in addition to the incentive effect, Newbery and Stiglitz (1979) claim that sharecropping can also be used as a self-selection device, in order to identify the characteristics of different individuals.
} 
changing circumstances; by contrast, cost-sharing contracts provide the ability and incentives for these adaptations, thus being more efficient (on this point see also Braverman and Stiglitz, 1982b).

According to Stiglitz (1989), the theory of sharecropping could explain not only the pervasiveness of this institution in developing economies, but also its decline in more developed countries. In these latter, in fact, mechanized agriculture may have lowered monitoring costs, thus reducing the main cost of a wage contract; at the same time, increasing wealth among some farmers and the development of alternative institutions for risk-sharing (such as future markets) may have reduced the need for risksharing through tenancy contracts, and hence made rental contracts more attractive.

Overall considered, sharecropping is regarded by the imperfect information theorists as an institutional adaptation to the lack of certain risk (insurance) markets. Indeed, in the absence of a complete set of markets, societies adapt to develop institutions that perform the functions that otherwise would have been served by the missing markets. However, these scholars tend to stress that even though institutions respond by performing some economic functions, this does not entail that they perform those functions optimally and that the resulting equilibrium is efficient (Stiglitz, 1989; Arnott and Stiglitz, 1984). Greenwald and Stiglitz (1986) have in fact shown that market allocations with incomplete markets and imperfect information are, in general, constrained Pareto-inefficient. With regard to sharecropping, this implies that since peasants are rational but not fully informed, the institutional rigidities caused by the presence of imperfect information are the source for the persistence of this seemingly inefficient institution.

A second important area of application of the imperfect information paradigm is the literature on interlocking of transactions in labor, credit, marketing and land lease. Broadly speaking, interlinking describes the simultaneous fixing of transactions between two parties over several markets, with the terms of one transaction contingent on the terms of another (Hoff et al, 1993). According to Bardhan (1989), this implies that interlinked transactions qualitatively differ from the anonymous and systemic interdependence of economic action in competitive general equilibrium theory. The usual examples of interlocking take the form of landlord-tenant relations intertwined with creditor-borrower relations between the same parties, or employers hiring workers on terms that are interlocked with those on which the former provide credit (or land) to the latter, or simultaneous deals in the commodity and credit 
markets between a trader and a farmer, where the latter gets credit on precommitment of future crop delivery to the former (Bardhan, 1989; Hoff et al, 1993).

In discussing the main economic features of interlinked transactions that characterize some agrarian institutions, Bardhan (1989) argues that a first distinctive trait of interlinking is that it allows saving on transaction costs. In this regard, the case of credit-labor linkage analyzed by Bardhan (1984) shows that the consumption credit supplied by the employer-creditor to the poor laborer - who is deficient in assets usable as collateral and will repay the loan in the form of future labor services - saves on transaction costs and ensures the double coincidence of wants without which the imperfectly monetized economies tend to be inefficient.

A second benefit of interlinked transactions is that they allow saving on contract enforcement costs by making the possible discovery of dishonesty, default or shirking by an agent in one transaction too costly for him in terms of its spillover effects threatening other transactions.

Thirdly, in situations of moral hazard with respect to unobserved work effort or risk-taking, interlinked transactions can internalize some externalities. In this context, Braverman and Stiglitz (1982a) analyze a tenancy-cum-credit contract and show that the landlord, by altering the terms and amount of the loan that he makes available to the tenant, can induce him to work harder or to undertake projects that are more to the liking of the landlord. Thus, if there is a positive externality of credit, there will be an incentive for the landlord to encourage the tenant to become indebted with him. Similarly, in order to explain credit interlinkage in the context of a sharecropping contract, Stiglitz (1986) points out that the problem of the landlord in inducing the worker both to work hard and to make the correct decisions from his point of view is analogous to lender's concern that the borrower will default on the loan. Therefore, since there are clear and possibly significant externalities between the actions of the landlord and the actions of the lender, a natural market solution is to internalize the externality via interlinkage. In this sense, the author argues that interlinkage is motivated by the desire for economic efficiency, not necessarily by the desire for further exploitation of the worker.

Finally, interlinked transactions provide a way of partially circumventing incomplete or nonexistent markets, particularly of credit and insurance. In this regard, Kotwal (1985) shows how, in the absence of an insurance market, credit as a weather-dependent side-payment in tenancy (i.e. in bad 
years the landlord gives credit to the tenant, who pays back in a better year) may solve the trade-off problem between risk-sharing and incentives that is central to the tenancy literature. Furthermore, Bardhan (1984) shows that by arranging various forms of seasonal labor-tying relationships with the worker - through wage advances, credit, or land allotment - the employer essentially substitutes for a future market in seasonal labor services.

Besides the above discussed benefits of interlinked transactions, Bardhan (1989) stresses also some possible drawbacks. Among these, the rationale for personalized interlinking may also act as a barrier to entry for third parties, thus being a source of additional monopoly power for the dominant partner in such transactions. Furthermore, by involving selective exclusion of others, personalized interlocking of labor commitments and credit transactions often divide the workers and weaken their collective bargaining strength vis-à-vis employers, who use this as an instrument for control in the labor process.

A further relevant application of the imperfect information theory regards the issues of credit rationing and joint liability in group lending schemes. Indeed, as Hoff and Stiglitz (1993) have pointed out, the advancements made during the last decades in understanding the workings of credit markets have evolved from the application of the theory emphasizing the problems of imperfect information and imperfect enforcement in lending relationships. A major problem for institutional lenders is, in fact, to ensure that borrowers exercise prudence in the use of the funds so that the likelihood of repayment is enhanced (Stiglitz, 1990). Several authors have suggested that peer monitoring represents an effective way of designing an incentive-monitoring system in a variety of settings with costly information (Arnott and Stiglitz, 1991). The general idea, as expressed by Banerjee et al. (1994), is that when the benefits for each member of a group depend in some defined way on the behavior of all the others, peer monitoring allows efficient monitoring of borrowers. Indeed, in the models analyzed by Stiglitz (1990), Hof and Stiglitz (1990), and Varian (1990) each member may continue to benefit from the loan only if all the other projects are successful; therefore, members have an incentive to control each other.

More in detail, Stiglitz's (1990) seminal model of peer monitoring is based on the assumption that each borrower has one (and only one) neighbor who is also a borrower, and both individuals can 
choose to undertake a risky or a safe project. ${ }^{34}$ Furthermore, the two borrowers can monitor each other, so that the lender would like each to report if his neighbor is undertaking the risky project. Therefore, in order to create an environment in which it is in the self-interest of each borrower to monitor the other and report any cheating, the lender offers a contract providing that if the neighbor agrees to cosign, the borrower can obtain a lower interest rate and additional funds. On the other hand, the cosigner agrees to pay a certain amount to the lender in the event that the loan he has cosigned goes into default, provided that he himself does not go into default. Given this specification of the model, it follows that the cosigner's expected utility depends on whether his neighbor undertakes the risky or the safe project; this interdependence between the two individuals makes it rationale for them to cooperate: they decide jointly which project to undertake, and in case they choose the risky one, they agree not to report it. An important point concerns the costs associated with peer monitoring, since by accepting to cosign his neighbor's loan, the individual imposes on him an additional risk. This implies that there is a transfer of risk from the lender, who is in a better position to bear risk, to the cosigners. However, Stiglitz (1990) shows that this transfer of risk leads to an improvement in borrowers' welfare: the risk burden imposed on the borrowers by cosigning is compensated by the reduction in the competitive interest rate charged and the availability of additional funds.

A successful peer monitoring practice, as reported by Stiglitz (1990), is represented by the Grameen Bank in Bangladesh, which is one of the many banking institutions that have been set up to provide credit in the rural sector of developing countries. This bank grants loans to groups of five individuals who live in the same village and are jointly responsible for repaying the loans. Moreover, noncompliance with bank rules by any member of the group curtails the borrowing opportunities of the other group members. Therefore, by devising this sort of incentive structure, whereby others in the village do the monitoring for it, the Grameen Bank is able to exploit the local knowledge of the group members.

\footnotetext{
${ }^{34}$ It is worth mentioning that in this model the success of borrowers' projects is independent.
} 


\section{THE EMPIRICAL EVIDENCE}

The discussion so far carried out suggests that there is a strong theoretical case supporting the importance of institutions in the organization of economic activity. However, the corresponding empirical case has been hampered by the lack of information on countries' institutional quality and also by problems related to its measurement. Nevertheless, empirical investigation of institutional issues has been increasingly undertaken. In particular, studies aimed at assessing the role of institutions and transaction costs in influencing economic outcomes rely on the use of proxy variables.

A first source of data for empirical analyses has been the International Country Risk Guide (ICRG) rankings produced by Political Risk Services. The ICRG rates 130 countries according to 24 categories. Knack and Keefer (1995) derive an index using the average of five of these categories (namely rules of law, bureaucratic quality, corruption, risk of expropriation and government repudiation of contracts) for the years 1986-1995. The authors find that the ICRG index has a statistically significant correlation with growth in standard growth regressions, even after controlling for education, initial income and other control variables typically used in growth regressions. Therefore, they claim that the institutional environment in which economic activity takes place is a determinant of countries performance.

Hall and Jones (1999) employ the same index used by Knack and Keefer (1995) across 127 countries to assess to what extent differences in capital accumulation, productivity and, therefore, output per worker are related to differences in the "social infrastructure". The latter expression is referred to the complex of institutions and public policies that determine the economic environment. In particular, Hall and Jones (1999) argue that the social infrastructure is favorable to high levels of output per worker when it supports individuals to accumulate skills, and firms to invest in capital and produce output. The empirical evidence stemming from this analysis suggests that there exists a close association between output per worker and measures of social infrastructure. Indeed, countries with long lasting policies favorable to productive activities tend to produce more output per worker. This result is robust even after controlling for the possible feedback effect that the variable output per worker may have on the social infrastructure, due to the fact that poor countries lack resources to build an effective social infrastructure. Therefore, Hall and Jones (1999) conclude that their work allows distinguishing 
between the proximate causes of economic success (capital accumulation and productivity) and the more fundamental determinant (social infrastructure).

An interesting contribution is offered by Acemoglu et al. (2001). To estimate the impact of institutions on economic performance they introduce a source of exogenous variation in institutions, derived from a theory of institutional diversity among countries colonized by Europeans. The theory proposed is based on three assumptions. Firstly, different types of colonization policies created diverse sets of institutions; ${ }^{35}$ secondly, the colonization strategy was influenced by the feasibility of settlements; finally, the colonial state and the corresponding institutions persisted even after independence. Based on these hypotheses, Acemoglu et al. (2001) use the mortality rates expected by European settlers in the colonies between the $17^{\text {th }}$ and the $19^{\text {th }}$ centuries and argue that the choice of the colonization policy depended upon the value of this rate. In particular, they claim that the higher the mortality rate was in a country, the more likely was the establishment of an extractive colonial settlement, that today is reflected in inefficient institutions and poor economic performance.

It appears evident that this hypothesis can be framed within the historical theoretical approach since it considers historic records fundamental to explain present conditions. Nonetheless, when the authors argue that current institutional patterns and economic outcomes are a result of past ones, reference to North and followers' concept of path dependence is practically explicit.

To test their conjecture Acemoglu et al. (2001), using a sample of 75 countries, regress current GDP per capita against current institutions, and instrument the latter by settler mortality rates. The empirical evidence seems to provide support to the historical theoretical approach since the results suggest that current institutions, inherited from the past, have a significant effect on current income per capita and this result is robust to several controls. Therefore, the authors claim that there exist sub-

\footnotetext{
${ }^{35}$ In particular, where "extractive states" were introduced there was scarce protection of property rights and against government abuses. The opposite happened where settlers intended to create what Crosby (1986) has called "Neo-Europes". An example of extractive state is the Belgian colonization of the Congo, while examples of Neo-Europes are Australia, Canada, and United States.
} 
stantial economic gains from improving institutions; however, on this point they do not provide any policy guideline.

In another study, Clague et al. (1995) argue that individuals can hold financial assets in form of cash and/or monetary instruments - called "contract-intensive money" - that involve other private parties. The authors use people's willingness to hold contract-intensive money as a proxy for countries' contract enforceability and, therefore, for institutional quality. Their empirical analysis finds that the proposed measure is significantly correlated with investments, hence, with economic growth even once the effects of inflation, real interest rates and other determinants of investments are taken into account.

To investigate the relationship existing between institutions and economic growth, Mauro (1995) uses bureaucratic corruption and efficiency as indicators for institutional quality. In particular, the data set consists of the Business International indexes on corruption and efficiency of the judicial system for 70 countries considered in the period 1980-1983. To address the issue of endogeneity, Mauro (1995) uses an index of ethno-linguistic fragmentation as an instrument. ${ }^{36}$ The empirical results provide evidence that bureaucratic efficiency causes higher investments and more rapid growth. Mauro (1995) shows that this relationship is robust to controls for standard determinants of investment and growth; therefore, he concludes that bureaucratic efficiency can be considered at least as important as political stability in determining investments and, thus, economic growth.

More recently, Keefer and Shirley (2000) have reported that the World Bank (1998) research investigating different combinations of macroeconomic policy and institutional quality, found that countries with high levels of institutional quality - measured in terms of security of contracts and property rights - and poor macroeconomic policies grew twice as fast as countries with the reverse combination. Therefore, the authors argue that a good macroeconomic policy does not appear to be enough to

\footnotetext{
${ }^{36}$ This index measures the probability that two individuals drawn at random from a country's population will not belong to the same etno-linguistic group. Etno-linguistic fragmentation is highly correlated with corruption and other instrumental variables. Yet, it can be assumed to be exogenous to both economic variables and institutional efficiency.
} 
trigger growth. Nevertheless, Keefer and Shirley achieved corroborating results when they undertook additional analysis using a panel of 84 countries considered in the period 1982-1994, and investigated whether the quality of institutions affected three policy variables, namely growth in government consumption, public investment, and public debt. These results seem to suggest that the insufficiency of macroeconomic policies to foster growth in an area might be explained using the historical interpretative framework. Indeed, good policies may perform inefficiently - at least in the short run - if implemented in low quality institutional contexts since these latter can be altered only through marginal and gradual changes.

An interesting contribution on the issue of institutional complementarities has been proposed by Ernst (2003). This study considers the interrelations that may exist between institutional arrangements on financial and labor markets, and that may produce effects on macroeconomic outcomes. The analysis is performed using data on output growth in 27 manufacturing industries in 19 OECD countries over the period 1979-1995. The empirical evidence provides strong support to the hypothesis of institutional complementarities between specific configurations of financial and industrial relations: they explain an important part of within industry variation among countries. Therefore, the comparative institutional approach appears to be validated by this investigation. More in detail, there is evidence that concentrated ownership structures and unionized industrial relations are complementary in promoting growth in industries with high skill levels, while individually these characteristics fail to produce the necessary incentives for investment. Similarly, concentration in ownership structures and employment protection are favorable to growth in bank financed industries, whilst ownership dispersion and labor market flexibility foster growth in equity financed industries. An important implication is, therefore, that policy modifications intervening in a market must offer incentives in line with those provided by the institutional arrangements prevailing on other markets.

In order to test the theory of rural organization based on rational peasants in environments where information is imperfect and markets are incomplete, Bardhan (1984) analyzes the sources of variation in forms of tenancy in India. As a departing point, Bardhan presents figures showing that sharecropping is the predominant form of tenancy in the Eastern and Northwestern parts of India, whilst fixed and rental tenancy are the prevailing forms in the Southern states. The aim of the subsequent 
theoretical analysis is to identify some of the factors that may determine this spatial variation in the presence of imperfect factors markets and different asset endowment characteristics of diverse types of tenants. The next step is to test empirically the propositions formulated. The results of the econometric investigation, implemented using intrastate cross-section data for the early 1950s, show that the tenanted area under sharecropping is higher in areas with larger prospect of unemployment faced by landless families, in more labor intensive crops, and in areas where the harvesting wage rate is higher. Furthermore, the empirical evidence suggests also that the share of land under sharecropping tends to be lower the larger the extent of imperfection in the credit market, and in areas where the insecurity of tenure on the sharecropper determines less land improvements. Overall considered, the study by Bardhan (1984) represents evidence in favor to the imperfect information theory of institutions, since it shows that different contractual arrangements (institutions) emerge as an appropriate response to the various problems created by incomplete markets and costly information.

\section{CONCLUSIONS}

The aim of this study has been to review the major literature analyzing the role of institutions in stimulating economic change, hence development. The interest in dealing with this issue has been motivated by the current widespread consensus in considering institutions as a crucial determinant shaping economic performance. The basic argument for such a view is that individuals can capture the gains from trade by cooperating. However, since cooperation is costly and harmed by opportunism, it is necessary to identify some device to overcome these problems. The evolution of institutions can produce a favorable environment for cooperative solutions that will enhance economic growth. The theoretical approaches proposed within the New Institutional Economics, as well as the empirical evidence stemming from several studies, clearly suggest that a country's long run economic success critically depends on its institutional framework.

A first theoretical approach proposed in this literature is the one elaborated by North (1990). This interpretative framework analyzes institutions from a historical perspective since, as Alston (1996) has argued, considering that much of the developmental path of societies is conditioned by their past 
in a path dependent way, it is necessary to take into account the specific historical context. The main message stemming from North’s analysis is that institutions affect economic performance by influencing the level of transaction costs and, hence, the feasibility and profitability of engaging in economic activity. In other words, institutions determine the opportunity set and provide a stable structure to human interaction by reducing uncertainty. The empirical evidence stemming from Acemoglu et al. (2001) seems to provide support to the historical theoretical approach since the results suggest that current institutions, inherited from the past, have a large effect on current income per capita. Nonetheless, the historical paradigm gains support from Keefer and Shirley's (2000) empirical analysis, as well. Indeed, considering their results, it could be argued that even good policies may perform inefficiently - at least in the short run - if implemented in low quality institutional contexts, since these latter can be adapted to meet new needs only through marginal and gradual changes.

An alternative analytical framework to the study of institutional issues is the comparative institutional approach, whose main trait is the attempt to consider not only the interdependencies existing across economic, political, social and organizational domains, but also those arising across institutions linking different domains. This approach has been applied to investigate two broad issues: on the one hand, attention has been given to the self-enforceability of institutions in the form of norms and conventions (evolutionary game approach); on the other hand, the origins and implications of endogenously determined organizations - such as banks, firms and merchant guilds - and the constraints implied by beliefs on agents behavior, have been the topic of several other analyses (repeated game approach). Within the comparative institutional approach, Aoki's (2001) analysis of institutional linkages shows that institutions may change the information and incentive structures of games, therefore making credible some strategic choices of agents that would not have been such otherwise. Moreover, the models elaborated on institutional complementarities show that the effects produced by one institution are reinforced when a complementary institution is present. The concept of institutional complementarity has, therefore, several implications in terms of policy recommendations since it suggests that any structural reform should consider the coherence and logic of the whole institutional structure (Amable, 2000), as well as its impact on the existing web of complementarities, and on the general context in which such complementarities are embedded (Boyer, 2005). The complementarity hypothesis 
has also received empirical support; indeed, Ernst (2003) has shown that the interrelations between institutional arrangements on financial and labor markets influence a country’s economic performance.

A further approach to the study of institutions and institutional issues is the theory of imperfect information, which explains the underlying rationale of institutions in terms of strategic behavior under asymmetric information among the different parties involved (Bardhan, 2000). This conceptual framework stresses that due to information and enforcement costs some markets will not exist and other markets will be largely uncompetitive, so that institutions have two major roles: firstly, they are a response to missing markets; secondly, they may help to overcome the information problems that preclude complete markets. The asymmetric information approach has been applied in modeling many agrarian and other institutions, which are seen to emerge as substitutes for missing credit, insurance and futures markets, in both developed and developing countries (Bardhan, 1984, 1989; Stiglitz, 1986). It started with the literature on sharecropping, then on interlocking of transactions in labor, credit, marketing and land lease, on labor tying, on credit rationing, on joint liability in group lending schemes, and so on (Bardhan, 1989). This analytical paradigm has been validated empirically by studies as Bardhan (1984), who has shown that imperfect markets and tenants' uneven asset endowment characteristics are factors affecting the observed spatial variation in tenancy contractual arrangements prevailing in India.

Despite the difficulties related to how to measure institutions, the existing econometric evidence suggests that institutions protecting property rights and enforcing the application of contracts foster economic development. Therefore, considering the relevance of these results, future research should be devoted to improve the feasibility of empirical studies and to provide a deeper understanding of the mechanisms driving particular types of institutions. One result, however, does not need to be further reconfirmed, nor by theory neither by practice: the institutional framework deeply influences economic change, hence economic performance. 


\section{REFERENCES}

Acemoglu, D., Johnson, S., Robinson, J.A., (2001). The Colonial Origins of Comparative Development. The American Economic Review 91(5), 1369-1401.

Acocella, N., (1999). Le istituzioni, in: Acocella, N. (Eds.), Istituzioni tra mercato e Stato. Carocci, Roma.

Ahn, T.K., Ostrom, E., (2003). Social Capital and Collective Action. Workshop in Political Theory and Policy Analysis, Indiana University.

Akerlof, G., (1970). The Market for “Lemons”: Qualitative Uncertainty and the Market Mechanism. Quarterly Journal of Economics 84, 488-500.

Alchian, A.A., (1950). Uncertainty, Evolution and Economic Theory. Journal of Political Economy 58, 211-221.

Alston, L.J., (1996). Empirical Work in Institutional Economics: an Overview, in: Alston, L.J., Eggertsson, T., North, D.C. (Eds.), Empirical Studies in Institutional Change. Cambridge University Press, Cambridge, pp. 25-30.

Alston, L.J., Higgs, R., (1982). Contractual Mix in Southern Agriculture since the Civil War: Facts, Hypotheses and Tests. Journal of Economic History 42, 327-353.

Amable, B., (2000). Institutional Complementarity and Diversity of Social Systems of Innovation and Production. Review of International Political Economy 7, 645-687.

Aoki, M., (1994). The Contingent Governance of Teams: Analysis of Institutional Complementarity. International Economic Review 35(3), 657-676.

Aoki, M., (1995). Organizational Conventions and the Gains from Diversity: An Evolutionary Game Approach. Working Paper, Stanford University.

Aoki, M., (1996). Towards a Comparative Institutional Analysis: Motivations and Some Tentative General Insights. Japanese Economic Review 47(1), 1-19.

Aoki, M., (2001). Toward a Comparative Institutional Analysis. MIT Press. 
Aoki, M., Dinc, S., (1997). Relational Financing a san Institution and Its Viability Under Competition. Working Paper, Stanford University.

Arnott, R., Stiglitz, J.E., (1984). Equilibrium in Competitive Insurance Markets: the Welfare Economics of Moral Hazard. Mimeo, Princeton University.

Arnott, R., Stiglitz, J.E., (1991). Moral Hazard and Nonmarket Institutions: Dysfunctional Crowding Out or Peer Monitoring?. American Economic Review 81, 179-190.

Arrighetti, A., Seravalli, G., (1999a). Sviluppo economico, convergenza e istituzioni intermedie, in: Arrighetti, A., Seravalli, G. (Eds.), Istituzioni intermedie e sviluppo locale. Donzelli, Roma.

Arrighetti, A., Seravalli, G., (1999b). Institutions and Coordination Costs. Working Paper n.6, Università di Parma.

Arthur, W.B., (1989). Competing Technologies, Increasing Returns, and Lock-In by Historical Events. Economic Journal 99, 116-131.

Arthur, W.B., (1994). Increasing Returns and Path Dependence in the Economy. The University of Michigan Press, Ann Arbor.

Banerjee, A.V., Besley, T., Guinnane, T.W., (1994). The Neighbour's Keeper: the Design of a Credit Cooperative with Theory and Test. The Quarterly Journal of Economics 109(2), 491-515.

Bardhan, P., Eds., (1984). Land, Labor, and Rural Poverty. Essays in Development Economics. Columbia University Press, New York.

Bardhan, P., Eds., (1988). Alternative Approaches to Development Economics: An Evaluation, in: Chenery, H.B., Srinivasan T.N., (Eds.), Handbook of Development Economics, Vol. 1, Elsevier Science Publishers, Amsterdam.

Bardhan, P., Eds., (1989). The Economic Theory of Agrarian Institutions. Clarendon Press, Oxford.

Bardhan, P., (2000). Understanding Underdevelopment: Challenges for Institutional Economics from the Point of View of Poor Countries. Journal of Institutional and Theoretical Economics 156 (1), 216-244. 
Basili, M., Duranti, C., Franzini, M., (2004). Network, Trust and Institutional Complementarities. Rivista di Politica Economica 1-2, 159-179.

Bednar, J., Page, S.E., (2005). Culture, Institutional Performance and Path Dependence, mimeo.

Bowles, S., (2001). Economic Institutions and Behavior: An Evolutionary Approach to Microeconomic Theory. Princeton University Press, Princeton, forthcoming.

Boyer, R., (2005). Coherence, Diversity, and the Evolution of Capitalisms. The Institutional Complementarity Hypothesis. Evolutionary and Institutional Economics Review 2(1), 43-80.

Braverman, A., Guasch, J.L., (1986). Rural Credit Markets and Institutions in Developing Countries: Lessons for Policy Analysis from Practice and Modern Theory. San Diego, University of California, Department of Economic Discussion Paper 86-6.

Braverman, A., Stiglitz, J.E., (1982a). Sharecropping and the Interlinking of Agrarian Markets. American Economic Review 72, 695-715.

Braverman, A., Stiglitz, J.E., (1982b). Moral Hazard, Incentive Flexibility and Risk: Cost Sharing Arrangements Under Sharecropping. Princeton University, Econometric Research Center Memorandum No. 298.

Braverman, A., Stiglitz, J.E., (1986a). Cost-sharing Arrangements Under Sharecropping: Moral Hazard, Incentive Flexibility, and Risk. American Journal of Agricultural Economics 68, 642-652.

Braverman, A., Stiglitz, J.E., (1986b). Landlords, Tenants, and Technological Innovations. Journal of Development Economics 23, 313-332.

Bromley, D.W., (1992). Making the Commons Work. Theory, Practice and Policy. ICS Press, San Francisco.

Calvert, R.L., (1995). Rational Actors, Equilibrium and Social Institutions, in: Knight, J., Sened, I. (Eds.), Explaining Social Institutions. University of Michigan Press, Ann Arbor, pp. 57-93.

Cheung, S.N.S., (1969). The Theory of Share Tenancy. University of Chicago Press, Chicago.

Clague, C., Keefer, P., Knack, S., Olson, M., (1995). Contract-Intensive Money: Contract Enforcement, Property Rights and Economic Performance. IRIS Working Paper, University of Maryland. 
Clay, K., (1997). Trade Without Law: Private Order Institutions in Mexican California. Journal of Law Economics and Organization 13(1), 202-31.

Coase, R., (1937). The Nature of the Firm. Economica 4, 386-405.

Coase, R., (1998). The New Institutional Economics. The American Economic Review 88(2), 72-74.

Collier, R.B., Collier, D., (1991). Shaping the Political Arena: Critical Junctures, the Labour Movement, and Regime Dynamics in Latin America. Princeton University Press, Princeton.

Commons, G.R., (1931). Institutional Economics. The American Economic Review 21(4), 648-657.

Crosby, A., (1986). Ecological Imperialism: The Biological Expansion of Europe 900-1900. Cambridge University Press, New York.

Crouch, C., Farrell, H., (2004). Breaking the Path of Institutional Development? Alternatives to the New Determinism. Rationality and Society 16(1), 5-43.

David, P., (1985). Clio and the Economics of QWERTY. The American Economic Review 75, 332-337.

Davis, L.E., North, D.C., (1971). Institutional Change and American Economic Growth. Cambridge University Press, Cambridge.

Easterly, W., (2001). The Elusive Quest for Growth: Economists’ Adventures and Misadventures in the Tropics. MIT Press, Cambridge MA.

Ernst, C.E., (2003). Financial Systems, Industrial Relations, and Industry Specialization. An Econometric Analysis on Institutional Complementarities. Paper presented at the OeNB Workshop "The Transformation of the European Financial System. Where Do We Go? Where Should We Go?”.

Ertman, T., (1997). Birth of the Leviathan. Cambridge University Press, Cambridge.

Fafchamps, M., (1996). Market Emergence, Trust and Reputation. Working Paper, Stanford University.

Gerschenkron, A., (1962). Economic Backwardness in Historical Perspective. Belknap, Cambridge. 
Granovetter, M.S., (1985). Economic Action and Social Structure: The Problem of Embeddedness. American Journal of Sociology 91(3), 481-510.

Greenwald, B.C., Glasspiegel, R.R., (1983). Adverse Selection in the Market for Slaves: New Orleans, 18301860. Quarterly Journal of Economics 98 (3), 479-499.

Greenwald, B., Stiglitz, J.E., (1986). Externalities in Economies with Imperfect Information and Incomplete Markets. Quarterly Journal of Economics 101, 229-264.

Greif, A., (1989). Reputations and Coalitions in Medieval Trade: Evidence on the Maghribi Traders. Journal of Economic History 49, 857-882.

Greif, A., (1993). Contract Enforceability and Economic Institutions in Early Trade: The Maghribi Traders’ Coalition. The American Economic Review 83(3), 525-548.

Greif, A., (1994a). Cultural Beliefs and the Organization of Society: A Historical and Theoretical Reflection on collectivist and Individualist Societies. Journal of Political Economy 102, 912-950.

Greif, A., (1994b). Trading Institutions and The Commercial Revolution in Medieval Europe, in: Aganbegyan, A., Bogomolov, O., Kaser, M. (Eds.), Economics in a Changing World, Vol. 1. Macmillan, London, pp. 115-25.

Greif, A., (1994c). Cultural Beliefs and the Organization of Society: A Historical and Theoretical Reflection on Collectivist and Individualist Societies. Journal of Political Economy 102(5), 912-950.

Greif, A., (1997a). Self-enforcing Political Systems and Economic Growth: Late Medieval Genoa. Mimeo, Stanford University.

Greif, A., (1997b). Microtheory and Recent Developments in the Study of Economic Institutions Trough Economic History, in: Kreps, D.M., Wallis, K.F. (Eds.), Advances in Economic Theory, Vol. 2. Cambridge University Press, Cambridge, pp. 79-133.

Greif, A., (1998a). Genoa and the Maghribi Traders: Historical and Comparative Institutional Analysis. Book manuscript.

Greif, A., (1998b). Historical and Comparative Institutional Analysis. The American Economic Review 88(2), 80-84. 
Greif, A., Milgrom, P., Weingast, B., (1994). Coordination, Commitment and Enforcement: The Case of the Merchant Guild. Journal of Political Economy 102, 745-776.

Hall, E., Jones, C.I., (1999). Why Do Some Countries Produce So Much More Output per Worker Than Others?. The Quarterly Journal of Economics 114(1), 83-116.

Hall, P.A., Soskice, D., (2001). An Introduction to Varieties of Capitalism, in: Hall, P.A., Soskice, D. (Eds.), Varieties of Capitalism. The Institutional Foundations of Comparative Advantage, Oxford University Press, pp. 1-68.

Hargreaves Heap, S.P., (1994). Institutions and (Short-Run) Macroeconomic Performance. Journal of Economic Surveys 8(1), 35-56.

Hodgson, G.M., (1998). The Approach of Institutional Economics. Journal of Economic Literature 36(1), 111-192.

Hodgson, G.M., (2006). What are Institutions?. Journal of Economic Issues XL(1), 1-25.

Hoff, K., Braverman, A., Stiglitz, J.E., Eds., (1993). The Economics of Rural Organization. Theory, Practice, and Policy. Oxford University Press, New York.

Hof, K., Stiglitz, J.E., (1990). Introduction: Imperfect Information and Rural Credit Markets. Puzzles and Policy Perspectives. World Bank Economic Review 4, 235-250.

Hoff, K., Stiglitz, J.E., (1993). Imperfect Information and Rural Credit Markets: Puzzles and Policy Perspectives. In: Hoff, K., Braverman, A., Stiglitz, J.E., Eds., The Economics of Rural Organization. Theory, Practice, and Policy. Oxford University Press, New York, pp. 33-52.

Hurwicz, L., (1993). Toward a Framework for Analyzing Institutions and Institutional Change, in: Bowles S., Gintis H., Gustafsson B. (Eds.), Markets and Democracy. Cambridge University Press, Cambridge, pp. 51-67.

Hurwicz, L., (1996). Institutions as Families of Game Form. Japanese Economic Review 47, 13-132.

Jensen, M.C., Meckling, W.H., (1976). Theory of the Firm: Managerial Behavior, Agency Costs and Ownership Structure. Journal of Financial Economics 3 (4), 305-360. 
Keefer, P., Shirley, M.M., (2000). Formal Versus Informal Institutions in Economic Development, in: Menard, C. (Eds.), Institutions, Contracts and Organizations. Perspectives from New Institutional Economics. Edward Elgar Publishing, pp. 88-107.

Kiwit, D., (1996). Path-Dependence in Technological and Institutional Change - Some Criticisms and Suggestions. Journal des Economistes et des Etudes Humaines 7(1), 69-93.

Klein, P.G., (1998). New Institutional Economics, in: Bouckeart, B., De Geest, G. (Eds.), Encyclopedia of Law and Economics. Edward Elgar and the University of Ghent, Chapter 0530, pp. 456-89.

Knack, P., Keefer, S., (1995). Institutions and Economic Performance: Cross-Country Tests Using Alternative Institutional Measures. Economics and Politics 7(3), 207-28.

Kotwal, A., (1985). The Role of Consumption Credit in Agricultural Tenancy. Journal of Development Economics 18, 273-295.

Mahoney, J., (2000). Path Dependence in Historical Sociology. Theory and Society 29(4), 507-548.

Mahoney, J., (2001a). Legacies of Liberalism: Path Dependence and Political Regimes in Central America. Johns Hopkins University Press, Baltimore.

Mahoney, J., (2001b). Path-Dependent Explanations of Regime Change: Central America in Comparative Perspective. Studies in Comparative International Development 36(1), 111-141.

Mauro, P., (1995). Corruption and Growth. The Quarterly Journal of Economics 110(3), 681-712.

Milgrom, P., North, D.C., Weingast, B., (1990). The Role of Institutions in the Revival of Trade: The Law Merchant, Private Judges, and the Champagne Fairs. Economics and Politics 2, 1-23.

Milgrom, P., Roberts, J., (1980). Rationalizability, Learning and Equilibrium in Games With Strategic Complementarities. Econometrica 59, 1255-1277.

Moore, B., (1996). Social Origins of Dictatorship and Democracy. Beacon Press, Boston.

Nabli, M., Nugent, J.B., (1989). The New Institutional Economics and Development. Theory and Applications to Tunisia. Elsevier, Amsterdam. 
Nelson, R.R., (1994). The Co-evolution of Technology, Industrial Structure and Supporting Institutions. Industrial and Corporate Change 3, 47-63.

Nelson, R.R., Sampat, B.N., (2001). Making Sense of Institutions as a Factor shaping Economic Performance. Journal of Economic Behavior and Organization 44, 31-54.

Newbery, D.M.G., Stiglitz, J.E., (1979). Sharecropping, Risk-sharing and the Importance of Imperfect Information, in: Roumasset, J.A., Boussard, J.M., Singh, I., (Eds.), Risk, Uncertainty, and Agricultural Development. Agricultural Development Council, New York.

North, D.C., (1981). Structure and Change in Economic History. Norton, New York.

North, D.C., (1990). Institutions, Institutional Change and Economic Performance. Cambridge University Press, Cambridge.

North, D.C., (1991). Institutions. The Journal of Economic Perspectives 5(1), 97-112.

North, D.C., Thomas, R.P., (1973). The Rise of the Western World: A New Economic History. Cambridge University Press, Cambridge.

Okazaki, T., Okuno-Fujiwara, M., (1996). Evolution of Economic Systems: The Case of Japan, in: Aoki, M., Hayami, H. (Eds.), The Institutional Foundations of Economic Development in East Asia. Macmillan, London.

Olson, M., (1965). The Logic of Collective Action. Cambridge University Press, Cambridge.

Ostrom, E., (1990). Governing the Commons. The Evolution of Institutions for Collective Action. Cambridge University Press, Cambridge.

Ostrom E., (1998). A Behavioural Approach to the Rational Choice Theory of Collective Action. American Political Science Review 92(1), 1-22.

Ostrom E., (2000). Collective Action and the Evolution of Social Norms. Journal of Economic Perspectives 14(3), 137-158.

Page, S.E., (2005). An Essay on the Existence and Causes of Path Dependence, mimeo. 
Pierson, P., (2000). Increasing Returns, Path Dependence, and the Study of Politics. American Political Science Review 92(4), 251-267.

Pierson, P., (2003). Politics in Time: History, Institutions, and Social Analysis. Princeton University Press, Princeton.

Pierson, P., (2004). Politics in Time: History, Institutions, and Social Analysis. Princeton University Press, Princeton.

Platteau, J.P., Seki, E., (2000). Community Arrangements to Overcome Market Failures: Pooling Groups in Japanese Fisheries, in: Aoki, M., Hayami, Y. (Eds.), Communities and Markets in Economic Development. Oxford University Press, Oxford.

Puffert, D.J., (1999). Path Dependence in Economic History. Institute for Economic History, University of Munich.

Rutherford, M., (1994). Institutions in Economics: The Old and The New Institutionalism. Cambridge University Press, Cambridge.

Rutherford, M., (1995). The Old and The New Institutionalism: Can Bridge Be Built?. Journal of Economic Issues 29, 443-450.

Rutherford, M., (2001). Institutional Economics: Then and Now. Journal of Economic Perspectives 3, $173-194$.

Schotter, A., (1981). The Economic Theory of Social Institutions. Cambridge University Press, Cambridge.

Schwartz, H., (2003). Down the Wrong Path: Path Dependence, Markets and Increasing Returns, mimeo.

Simon, H.A., (1947). Administrative behaviour. The Free Press, New York.

Spagnolo, G., (1999). Social Relations and Cooperation in Organizations. Journal of Economic Behavior and Organization 38, 1-25.

Stiglitz, J.E., (1974). Incentives and Risk Sharing in Sharecropping. Review of Economic Studies 41, 219-255. 
Stiglitz, J.E., (1985). Economics of Information and the Theory of Economic Development. Revista De Econometria 5 (1), 5-32.

Stiglitz, J.E., (1986). The New Development Economics. World Development 14(2), 257-265.

Stiglitz, J.E., (1989). Rational Peasants, Efficient Institutions, and a Theory of Rural Organization: Methodological Remarks for Development Economics, in: Bardhan, P., Eds., The Economic Theory of Agrarian Institutions. Clarendon Press, Oxford.

Stiglitz, J.E. 1990. Peer monitoring and credit markets. World Bank Economic Review 4, 351-366.

Stiglitz, J., (1998). More Instruments and Broader Goals: Moving Toward the Post-Washington Consensus. Wider Annual Lectures 2. United Nations World Institute for Development Economics Research, Helsinki, Finland. Processed.

Sugden, R., (1986). The Economics of Rights, Co-operation and Welfare. Basil Blackwell, Oxford.

Sugden, R., (1989). Spontaneous Order. Journal of Economic Perspectives 3, 85-97.

Thelen, K., (1999). Historical Institutionalism in Comparative Politics. Annual Review of Political Science, 369-404.

Tirole, J., (1996). A Theory of Collective Reputations (with Applications to the Persistence of Corruption and to Firm Quality). The Review of Economic Studies 63(1), 1-22.

Topiks, D., (1978). Minimizing a Submodular Function on a Lattice. Operations Research 26, 305-21.

Topiks, D., (1998). Supermodularity and Complementarity. Princeton University Press, Princeton.

Varian, H.R., (1990). Monitoring Agents with Other Agents. Journal of Institutional and Theoretical Economics 146, 153-174.

Veblen, T.B., (1899). The Theory of the Leisure Class: An Economic Study in the Evolution of Institutions. Macmillan, New York.

Veblen, T.B., (1919). The Place of Science in Modern Civilization and Other Essays. Huebsch, New York. 
Wallis, J.J., North, D.C., (1986). Measuring the Transaction Sector in the American Economy: 1870 to 1970, in: Engerman, S.L., Gallman, R.E. (Eds.), Long Term Factors in American Economic Growth, Studies in Income and Wealth, 51, University of Chicago Press, Chicago.

Williamson, O.E., (1975). Markets and Hierarchies: Analysis and Antitrust Implications. Free Press, New York.

Williamson, O.E., (1979). Transaction-Cost Economics: the Governance of Contractual Relations. Journal of Law and Economics 22 (2), 233-261.

Williamson, O.E., (1985). The Economic Institutions of Capitalism. Free Press, New York.

Williamson, O.E., (1996). The Mechanisms of Governance. Oxford University Press, Oxford.

Williamson, O.E., (2000). The New Institutional Economics: Taking Stock, Looking Ahead. Journal of Economic Literature 38, 595-613.

World Bank, (1993). The East Asian Miracle: Economic Growth and Public Policy. Oxford University Press, New York.

World Bank, (1997). World Development Report: The State in a Changing World. Oxford University Press, New York.

World Bank, (1998). Dividends and disappointments: Learning from the success and failure of foreign aid. World Bank, Discussion Draft, July.

World Bank, (2003). World Development Report: Sustainable Development in a Dynamic World. Transforming Institutions, Growth, and Quality of Life. Oxford University Press, New York.

Young, H.P., (1993). The Evolution of Conventions. Econometrica 61(1), 57-84.

Young, H.P., (1998). Individual Strategy and Social Structure: An Evolutionary Theory of Institutions. Princeton University Press, Princeton. 